\title{
PENGARUH FAKTOR PERSONAL, FAKTOR ORGANISASIONAL DAN FAKTOR NON ORGANISASIONAL TERHADAP KOMITMEN ORGANISASIONAL KARYAWAN PT AJB BUMI PUTRA GONDOMANAN YOGYAKARTA
}

\author{
Iksan Mulyono \\ iksanagung81@gmail.com \\ Universitas Ahmad Dahlan \\ Utik Bidayati \\ utikbidayati@yahoo.com \\ Universitas Ahmad Dahlan
}

\begin{abstract}
ABSTRAK
This study aims to determine the influence of personal factors, factors organizational and non-organizational factors towards organizational commitment employees at PT. AJB Bumi Putera Gondomanan Yogyakarta. This research is a survey research using a questionnaire as the instrument. The population in this study consisted of 40 employees who worked at PT. AJB Bumi Putera Gondomanan Yogyakarta. The sample in this study totaling 40 employees at PT. AJB Bumi Putera Gondomanan Yogyakarta. The population in this study were all employees of PT.AJB Bumi Putera Gondomanan Yogyakarta. Which uses the Sampling method saturation that is taking all the number of employees. The type of data used is primary data. Data is obtained directly from the source or object research is by distributing questionnaires. The results of panel data regression analysis with a significant level of 0.05 can be obtained it was concluded that the 0.173 personal factor hypothesis had no effect on organizational commitment, the second hypothesis of organizational factors 0.296 no effect on organizational commitment, the third hypothesis is non factors organizational 0,008 has a significant effect on organizational commitment, the fourth hypothesis is personal factors, organizational factors and non factors organizational significant effect simultaneously on commitment organizational value of 0.025 .
\end{abstract}

Keywords: Personal Factors, Organizational Factors, Non-Organizational Factors and Organizational Commitment.

\section{PENDAHULUAN}

Keberlangsungan sebuah perusahaan sangat tergantung pada peran tenaga kerja, mulai dari pimpinan hingga pekerja tingkat dasar. Hal ini bukan berarti perusahaan mengeksploitasi para pekerjanya, tetapi para pekerjalah yang menjadi tombak utama sebuah perusahaan untuk bertahan dan berkembang pesat. Tenaga kerja atau sering disebut pegawai maupun karyawan memiliki fungsi untuk mempertahankan produktifitas perusahaan, menjalin hubungan baik dengan pihak internal maupun eksternal perusahan dan menjaga nama baik perusahaan dengan menciptakan produk atau jasa yang berkualitas. Untuk mendapatkan pegawai atau karyawan yang membantu perusahaan mencapai tujuannya, dibutuhkan sebuah komitmen organisasional.

Hal di atas menyiratkan bahwa komitmen organisasional karyawan menjadi salah satu faktor penting, kesuksesan perusahaan dalam bersaing dengan perusahaan lain. Komitmen organisasional saat ini tidak bisa disepelekan karena perekonomian Indonesia semakin terbuka dan memaksa perusahaan-perusahaan Indonesia untuk 
bersaing dengan perusahaan-perusahaaan sejenis baik dalam negeri maupun luar negeri. Salah satu perusahaan besar yang telah berdiri cukup lama dan memiliki banyak karyawan adalah PT AJB BUMI PUTRA.

Menurut Robert (2014) bahwa komitmen organisasi adalah cerminan dimana seorang karyawan dalam mengenali organisasi dan terikat kepada tujuan-tujuannya. Ini adalah sikap kerja yang penting karena orang-orang memiliki komitmen diharpakn mampu bekerja lebih keras demi mencapai tujuan organisasi dan memiliki hasrat yang lebih besar untuk tetap bekerja di suatu persuhaan. Steers dan Porter dalam Sopiah (2008) mengemukakan faktor yang mempengaruhi komitmen karyawan pada organisasi adalah faktor personal. Lincoln dan Bashaw dalam Sopiah (2008) menyebutkan bahwa komitmen organisasi dipengaruhi oleh faktor orgnisasional dan menurut Steers dan Porter dalam Sopiah (2008) selain faktor organisasional, faktor yang ketiga adalah faktor non organisasional. Berdasarkan pendapat para ahli di atas dapat disimpulkan bahwa ada beberapa faktor yang menyebabkan/mempengaruhi komitmen organisasional karyawan yaitu Faktor personal, faktor organisasional dan faktor non organisasional.

Steers dan Porter dalam Sopiah (2008) mengemukakan faktor yang mempengaruhi komitmen karyawan pada organisasi, yaitu faktor personal yang meliputi personal characteristic atau karakteristik individu. Faktor pembentuk komitmen yang paling awal dalam diri individu adalah faktor personal. Karakteristik personal setiap manusia berbeda-beda antara satu dengan yang lain. Karakteristik merupakan ciri atau kemampuan untuk memperbaiki kualitas hidup (Kamus Besar Bahasa Indonesia/KBBI). Komitmen organisasional disebabkan salah satunya oleh karakteristik personal (Luthan, 2015). Variabel personal yang memiliki keterlibatan adalah usia dan masa kerja, tingkat pendidikan, jenis kelamin, dan status perkawinan. Dalam upaya memperoleh karakteristik personal karyawan yang baik sesuai dengan kebutuhan organisasi, perusahaan menuntut setiap karyawan agar memiliki komitmen yang tinggi dalam bekerja. Menurut Siswanto (2013), seorang individu yang memiliki kinerja dan komitmen yang tinggi dalam menyelesaikan tugasnya di perusahaan sesuai dengan tanggung jawab yang diberikan kepadanya dapat ditunjukkan dengan beberapa kriteria karyawan, seperti kesetiaan, tanggung jawab, inisiatif, dan ketepatan waktu dalam setiap pekerjaan yang dilakukannya.

Lincoln dan Bashaw dalam Sopiah (2008) menyebutkan bahwa komitmen organisasi dipengaruhi oleh faktor orgnisasional yang merupakan faktor yang berasal dari dalam suatu organisasi seperti kepemimpinan. Menurut Thoha (2010) kepemimpinan adalah sifat, karakter, atau cara seseorang dalam upaya membina dan menggerakkan seseorang atau sekelompok orang agar mereka bersedia, komitmen dan setia untuk melaksanakan kegiatan sesuai dengan tugas dan tanggung jawab untuk mewujudkan tujuan organisasi yang telah ditetapkan sebelumnya. Robbins (2014), mengemukakan bahwa kepemimpinan adalah sebagai kemampuan untuk mempengaruhi suatu kelompok kearah tercapainya tujuan.

Menurut Steers dan Porter dalam Sopiah (2008) Non-organizational Factor meliputi availability of alternative jobs. Faktor yang bukan berasal dari dalam organisasi, misalnya ada tidaknya alternatif pekerjaan lain. Jika ada dan lebih baik, tentu pegawai akan meninggalkannya. Sama halnya yang disampaikan oleh Greenberg (2005) yang mengemukakaan bahwa Keberadaan kesempatan kerja alternatif dan adanya kesempatan yang besar untuk memperoleh pekerjaan di luar organisasi tempat karyawan bekerja cenderung akan 
mendorong turunnya komitmen organisasi karyawan jika kesempatan kerja alternatif yang ada memberikan manfaat yang lebih besar baik secara finansial maupun non finansial.

\section{PT. AJB BUMI PUTERA} GONDOMANAN YOGYAKARTA merupakan persuahaan yang bergerak di bidang jasa sauransi di tuntut mampu berkompotensi dengan kompetitor yang bergerak di bidang usaha yang sama, untuk itu diperlukan sumber daya manusia yang berkompoten. Guna mencapai visinya "BUMI PUTERA ingin menjadi asuransinya Bangsa Indonesia", PT AJB BUMI PUTERA perlu didukung oleh para karyawan yang mempunyai keahlian, kemampuan, serta kapasitasnya masingmasing. Dimana dalam hal ini diperlukan Komitmen dari diri setiap individu/karyawan, karena semakin tinggi komtimen seorang individu/karyawan maka akan semakin baik kinerjanyan dan mampu membantu perusahaan untuk mencapai visinya.

Tujuan dari penelitian ini di antaranya: 1) untuk mengetahui apakah terdapat pengaruh faktor personal terhadap komitmen karyawan di PT. AJB BUMI PUTRA YOGYAKARTA, 2) untuk mengetahui pakah terdapat pengaruh faktor organisasional terhadap komitmen karyawan di PT. AJB BUMI PUTRA YOGYAKARTA, 3) untuk mengetahui apakah terdapat pengaruh faktor non organisasional terhadap komitmen karyawan di PT.AJB BUMI PUTRA YOGYAKARTA dan 4) untuk mengetahui apakah terdapat pengaruh faktor personal, faktor organisasional dan faktor non organisasional terhadap komitmen karyawan di PT.AJB BUMI PUTRA YOGYAKARTA.

\section{REVIEW LITERATUR DAN HIPOTESIS}

\section{Landasan Teori}

1. Faktor Personal

Faktor personal yang dimiliki oleh setiap manusia antara yang satu dengan yang lain berbeda-beda. Robbins (2014) mengemukakan bahwa karakteristik personal adalah cara memandang ke obyek tertentu dan mencoba menafsirkan apa yang dilihatnya mencakup usia, jenis kelamin dan tingkat pendidikan. Karakteristik personal mencakup sifat-sifat berupa kemampuan dan ketrampilan, latar belakang keluarga, sosial, pengalaman, umur, kebangsaan, jenis kelamin, dan lainnya yang mencerminkan sifat demografis tertentu, serta karakteristik psikologis yang terdiri atas presepsi, sikap, kepribadian, belajar, dan motivasi.

Pada tingkatan individu, karakteristik dari masing-masing individu (personal) yang meliputi: ciri pribadi atau biografis seperti: usia, gender, status perkawinan, ciri kepribadian, nilai dan sikap dan tingkat kemampuan dasar akan mempengaruhi perilaku mereka di tempat kerja (Lumbanraja, 2009). Dari pernyataan tersebut dapat dikatakan bahwa karakteristik seperti usia, gender dan pendidikan berhubungan signifikan terhadap variabel dependen penelitian ini. Namun, dalam penelitiannya faktor demografi ini pada umumnya dijadikan variabel kontrol dalam penelitian sebelumnya. Oleh karena itu, dalam penelitian ini yang menjadi salah variabel yang diangkat peneliti adalah karakteristik demografi yang usia, jenis kelamin, status pernikahan, dan masa kerja. 
2. Faktor Organisasional

Lincoln dan Bashaw dalam Sopiah (2008) menyebutkan bahwa komitmen organisasi dipengaruhi oleh faktor orgnisasional yang merupakan faktor yang berasal dari dalam suatu organisasi seperti kepemimpinan dan kompensasi, dari peryataan ahli tersebut peneliti memilih untuk membahas pentingnya kepemimpinan di dalam suatu organisasi karena Suatu organisasi atau perusahaan diperlukan seorang pemimpin yang mampu membawa perusahaan mempertahankan konsistensi dan bersaing di dunia bisnis. Begitu penting peran kepemimpinan dalam perusahaan atau organisasi dalam pencapaian suatu misi, visi dan tujuan. Tidak adanya seorang pemimpin dapat menjadikan suatu perusahaan atau organisasi mengalami kemunduran. Bass (1990) dalam Darmawan (2017) yang menyatakan bahwa kualitas dari pemimpin sering dianggap sebagai faktor terpenting yang menentukan keberhasilan atau kegagalan organisasi. Organisasi membutuhkan kepemimpinan yang kuat agar efektivitasnya optimal (Robbins, 2014).

$$
\text { Menurut Thoha }
$$

kepemimpinan adalah sifat, karakter, atau cara seseorang dalam upaya membina dan menggerakkan seseorang atau sekelompok orang agar mereka bersedia, komitmen dan setia untuk melaksanakan kegiatan sesuai dengan tugas dan tanggung jawab untuk mewujudkan tujuan organisasi yang telah ditetapkan sebelumnya. Robbins (2014), mengemukakan bahwa kepemimpinan adalah Sebagai kemampuan untuk mempengaruhi suatu kelompok kearah tercapainya tujuan. Berdasarkan kutipan di atas, kepemimpinan adalah kemampuan seseorang dalam menggerakan dan memanfaatkan sumber daya organisasi untuk mencapai tujuan yang telah ditentukan.

\section{Faktor Non-Organisasional}

Faktor non organisasional adalah faktor yang bukan berasal dari dalam organisasi. Dimana diera globalisasi seiring dengan kebutuhan karyawan maka karyawan cenderung akan mencari alternaitf pekerjaan yang lain yang menurutnya lebih baik daripada pekerjaan sebelumnya.

Menurut Steers dan Porter dalam Sopiah (2008) Non-organizational faktor meliputi availability of alternative jobs. Faktor yang bukan berasal dari dalam organisasi, misalnya ada tidaknya alternatif pekerjaan lain. Jika ada dan lebih baik, tentu pegawai akan meninggalkannya. Sama halnya yang disampaikan oleh Greenberg (2005) yang mengemukakaan bahwa keberadaan kesempatan kerja alternatif dan adanya kesempatan yang besar untuk memperoleh pekerjaan di luar organisasi tempat karyawan bekerja cenderung akan mendorong turunnya komitmen organisasi karyawan jika kesempatan kerja alternatif yang ada memberikan manfaat yang lebih besar baik secara finansial maupun non finansial.

Faktor non organisasional merupakan faktor yang menunjukan ciri dari suatu jenis pekerjaan atau faktor yang membedakan antara suatu pekerjaan dengan jenis pekerjaan lainnya (Steers dan Porter dalam Sopiah, 2008).

Indikator pengukuran yang diambil dari penelitian Husin (2014) adalah:

a. Pekerjaan pilihan: sesuai dengan keahlian.

b. Perusahaan lain yang lebih baik: level perusahaan (internasional).

c. Pekerjaan lain yang lebih baik: kondisi dan lingkungan pekerjaan. 
4. Komitmen Organisasional

Komitmen organisasional sebagai sebuah keadaan psikologi yang mengkarakteristikan hubungan karyawan dengan organisasi atau implikasinya yang mempengaruhi apakah karyawan akan tetap bertahan dalam organisasi atau tidak, yang teridentifikasi dalam tiga komponen yaitu komitmen afektif, komitmen kontinyu, dan komitmen normatif (Zurnali, 2010).

Luthans (2011), mendefinisikan komitmen organisasi sebagai: (1) $a$ strong desire to remain a member of a particular organization; (2) a willingness to exert high levels of effort on behalf of the organization; and (3) a definite belief in, and acceptance of, the values and goals of the organization. Dengan demikian, komitmen organisasi berarti:

a. Keinginan kuat untuk tetap sebagai anggota organisasi tertentu,

b. Keinginan untuk berusaha keras sesuai keinginan organisasi,

c. Keyakinan tertentu, dan penerimaan nilai dan tujuan organisasi).

$$
\text { Komitmen organisasional }
$$

menurut Arishanti (2009) adalah kepercayaan dan penerimaan yang kuat terhadap nilai-nilai organisasi, kemauan untuk bekerja keras, dan memelihara keanggotaannya dalam organisasi yang bersangkutan, yang berarti ada keinginan yang kuat daari anggota untuk tetap berada dalam organisasi atau adanya ikatan psikologis terhadap organisasi. Komitmen organisasi dalam tujuan kita adalah sebagai kekuatan relatif dari identifikasi individu dan keterlibatan dengan organisasi (Robbins, 2014).

Berdasar beberapa pendapat di atas dapat disimpulkan bahwa definisi komitmen organisasional adalah kemampuan pada karyawan dalam mengidentifikasi dirinya dengan nilainilai, aturan-aturan, tujuan organisasi atau perusahaan, mencakup unsur loyalitas terhadap perusahaan, dan keterlibatan dalam pekerjaan. Indikator pengukuran komitmen organisasional (Y) yang diambil dari penelitian Husin (2014) yaitu:

a. Karyawan bangga sebagai bagian dari organisasi.

b. Organisasi memberikan inspirasi terbaik.

c. Peduli terhadap nasib organisasi.

\section{Penelitian Terdahulu}

Husin (2014) melakukan penelitian dengan judul "pengaruh variabel personal, organiasional dan non organisasional terhadap komitmen orgasnisasional (Studi Pada Karyawan Perusahaan PT. PLN ( Persero) APJ Malang Distribusi Jawa Timur)". Hasilnya faktor personal berpengaruh signifikan terhadap komitmen organisasional dengan $\mathrm{t}$ hiutng sebesar $0,002<0,05$. Faktor organisasional berpengaruh signifikan terhadap komitmen organisasional dengan $\mathrm{t}$ hiutng sebesar $0,000<0,05$. Faktor non-organisasional berpengaruh signifikan terhadap komitmen organisasional dengan $\mathrm{t}$ hiutng sebesar $0,028<0,05$. Faktor personal, faktor organisasional, faktor non organisasional berpengaruhsignifikan secara simultan terhadap komitmen organisasional dengan f hiutng sebesar $0,000<0,05$.

Munandar (2017) melakukan penelitian dengan judul "pengaruh faktor personal, faktor organisasional dan faktor non organnisasional terhadap komitmen organisasional (Studi Kasus pada Karyawan PT KAI DAOP 6 Yogyakarta Stasiun Lempuyangan)". Hasilnya faktor personalberpengaruh signifikan terhadap komitmen organisasional dengan t hiutng sebesar $0,007<0,05$. Faktor organisasional berpengaruh signifikan terhadap komitmen organisasional dengan 
t hitung sebesar $0,030<0,05$. Faktor nonorganisasional berpengaruh signifikan terhadap komitmen organisasional dengan t hitung sebesar $0,004<0,05$.

\section{Hipotesis}

H1: Faktor personal berpengaruh signifikan terhadap komitmen organisasional karyawan.

$\mathrm{H} 2$ : Faktor organisasional berpengaruh signifikan terhadap komitmen organiasional.

H3: Faktor non organisasional berpengaruh signifikan terhadap komitmen organiasional.

H4: .Faktor personal, faktor organisasional dan faktor non organisasional berpengaruh signifikan secara simultan terhadap komitmen organisasional.

\section{METODE PENELITIAN}

\section{Populasi dan Sampel}

Menurut Sugiyono (2009) populasi adalah wilayah generalisasi yang terdiri atas obyek/subyek yang mempunyai kualitas dan karakteristik tertentu yang ditetapkan oleh peneliti untuk dipelajari dan kemudian ditarik kesimpulannya. Dalam penelitian ini, populasinya adalahseluruh karyawan PT. AJB BUMI PUTRA GONDOMANAN yang berjumlah 40 karyawan.

Menurut Sugiyono (2009) sampel adalah bagian dari jumlah dan karakteristik yang dimiliki oleh populasi tersebut. Dalam penelitian ini teknik pengambilan sampel dalam penelitian ini adalah dengan menggunakan sampel jenuh karena semua anggota populasi digunakan sebagai sampel, yaitu seluruh karyawan PT. AJB BUMI PUTRA GONDOMANAN Deresan dengan jumlah 40 karyawan.

\section{Definisi Operasional}

1. Variabel Independen

a. Faktor Personal (X1), bahwa karakteristik personal adalah cara memandang ke obyek tertentu dan mencoba menafsirkan apa yang dilihatnya mencakup usia, jenis kelamin, status perkawinan, dan masa kerja dalam organisasi (Robbins, 2014).

b. Faktor Organisasional (X2), menyebutkan bahwa komitmen organisasi dipengaruhi oleh faktor orgnisasional yang merupakan faktor yang berasal dari dalam suatu organisasi seperti kepemimpinan. (Lincoln dan Bashaw dalam Sopiah, 2008).

c. Faktor Non-Organisasional (X3), merupakan faktor yang menunjukan ciri dari suatu jenis pekerjaan atau faktor yang membedakan antara suatu pekerjaan dengan jenis pekerjaan lainnya (Steers dan Porter dalam Sopiah, 2008).

\section{Variabel Dependen}

Komitmen organisasional sebagai suatu keadaan dimana seorang individu memihak organisasional serta tujuan dan keinginannya untuk mempertahankan keanggotaannya dalam organisasional (Robbin, 2014).

\section{Uji Instrumen}

\section{Uji Validitas}

Uji validitas digunakan untuk menguji dan mengetahui ketepatan dan kecermatan alat ukur. Proses pengujian pengujian validitas dilakukan dengan membandingkan nilai $r$ hitung, untuk $\mathrm{r}$ hitung tiap butir dapat dilihat pada lampira output crombach alpha pada kolo (corrected item-Total correlation) dengan $r$ tabel untuk degree of freedom (df) $=\mathrm{n}-2$, dalam hal ini $\mathrm{n}$ adalah jumlah sampel. Dalam penelitian ini 
jumlah sampel $(\mathrm{n})=30$ dan besarnya $\mathrm{df}$ dapat dihitung $30-2=2$, dengan df 28 dan alpha 0,05 didapat $r$ tabel $=0,374$. Jika $r$ hitung $>r$ tabel dan nilai positif, maka butir atau peryantaan atau indikator tersebut dinyatakan valid. Jumlah ukuran sampel yang digunakan untuk uji validitas adalah sebesar 30 responden.

Item-item yang mengukur konsep yang sama akan memiliki korelasi yang tinggi dan berkorelasi rendah dengan item-item yang mengukur konsep yang berbeda (Ghozali, 2011). Hal ini ditunjukkan dengan muatan faktor item yang tinggi pada satu faktor yang seharusnya diukur saja dan bermuatan faktor rendah pada faktor rendah yang diukur oleh itemitem.

\section{Uji Reliabilitas}

Uji reliabilitas dilakukan untuk menguji kuisioner yang merupakan indikator dari variabel konstruk. Suatu kuisioner dikatakan reliabel atau handal jika jawaban seseorang terhadap pernyataan adalah konsisten atau stabil dari waktu ke waktu (Ghozali, 2011), sedangkan untuk uji reliabilitas yang akan digunakan dalam penelitian ini, yaitu dengan uji statistik pearson correlattion. Suatu variabel atau konstruk dinyatakan reliabel jika nilai cronbach aplha $\geq 0,60$ (Ghozali, 2011).

\section{Teknik Analisis Data}

1. Analisis Regresi Berganda

Analisis regresi linier berganda digunakan untuk mengukur pengaruh antara variabel independen yang terdiri atas faktor personal, faktor organisasional, faktor non organisasional terhadap variabel dependen komitmen karyawan. Dalam penelitian ini, model regresi yang digunakan sebagai berikut:

$\mathrm{Y}=\alpha+\mathrm{b} 1 \mathrm{X} 1+\mathrm{b} 2 \mathrm{X} 2+\mathrm{b} 3 \mathrm{X} 3$ $\begin{array}{ll}\text { Y } & \text { : Komitmen Karyawan } \\ \text { a } & \text { : Konstanta }\end{array}$

b1,b2,b3 : Koefisien Regresi

$\mathrm{X} 1$ : Faktor Personal

X2 : Faktor Organisasional

X3 : Faktor Non-Organisasional

\section{Uji Hipotesis}

\section{Uji Parsial (Uji T)}

Dalam penelitian ini uji $t$ digunakan untuk mengetahui pengaruh variabel dependen (Ghozali, 2011). Dengan kriteria penerimaan hipotesis sebagai berikut:

a. Jika tingkat signifikansi $<0,05$, maka Ho ditolak dan Ha diterima

b. Jika tingkat signifikansi > 0,05, maka Ho diterima dan Ha ditolak

2. Uji Simultan (Uji F)

Uji $F$ pada dasarnya menunjukkan apakah semua variabel independen atau bebas yang dimasukkan dalam model mempunyai pengaruh secara bersama-sama terhadap variabel dependen atau terikat (Ghozali, 2011). Untuk mengetahui signifikansi atau tidaknya pengaruh variabel bebas terhadap variabel terikat secara simultan maka digunakan sebesar 5\%.

a. Jika tingkat signifikansi $<0,05$, maka Ho ditolak dan Ha diterima

b. Jika tingkat signifikansi >0,05, maka Ho diterima dan Ha ditolak

\section{Uji Koefisien Determinasi}

Koefisien determinasi digunakan untuk menguji goodness fit dan model regresi (Ghozali, 2011). Dalam pengujian ini, koefisien determinasi dilihat dari besarnya nilai $R$-Square. Nilai koefisien determinasi ( $R$-Square) dapat digunakan untuk memprediksi seberapa besar kontribusi pengaruh variabel independen terhadap variabel dependen dengan syarat hasil uji $F$ dalam analisis regresi bernilai signifikan. Sebaliknya, jika hasil dalam 
uji $F$ tidak signifikan maka nilai koefisien determinasi ( $R$-Square) tidak dapat digunakan untuk memprediksi kontribusi pengaruh variabel independen terhadap variabel dependen. Nilai koefisien determinasi antara 0 sampai 1. Apabila didapat hasil mendekati angka 1, artinya menunjukkan model regresi sangat kuat dalam menerangkan keragaman variasi variabel dependennya. Tetapi apabila hasilnya mendekati angka 0 artinya semakin lemah variabel independnnya dalam menerangkan variabel dependen.

\section{HASIL PENELITIAN DAN PEMBAHASAN}

\section{Hasil Analisis Responden}

Data Responden Berdasarkan Jenis Kelamin

\begin{tabular}{|l|c|c|}
\hline \multicolumn{1}{|c|}{ Jenis Kelamin } & Frequency & Percent \% \\
\hline Laki - laki & 13 & $32,5 \%$ \\
\hline Perempuan & 27 & $67,5 \%$ \\
\hline Jumlah & $\mathbf{4 0}$ & $\mathbf{1 0 0} \%$ \\
\hline
\end{tabular}

Berdasarkan tabel di atas, menunjukkan bahwa karyawan yang berjenis kelamin laki-laki sebanyak 13 orang responden $(32,5 \%)$ sedangkan karyawan yang berjenis kelamin perempuan sebanyak 27 orang responden $(67,5 \%)$. Dengan demikian mayoritas responden dari karyawan PT. AJB Bumi Putera Gondomanan Yogyakarta berjenis kelamin perempuan.

Data Responden Berdasarkan Pendidikan Terakhir

\begin{tabular}{|l|c|c|}
\hline \multicolumn{1}{|c|}{$\begin{array}{c}\text { Pendidikan } \\
\text { Terakhir }\end{array}$} & Frequency & Percent \% \\
\hline SMA & 12 & $30 \%$ \\
\hline Diploma & 17 & $42,5 \%$ \\
\hline Sarjana & 11 & $27,5 \%$ \\
\hline Jumlah & $\mathbf{4 0}$ & $\mathbf{1 0 0} \%$ \\
\hline
\end{tabular}

Pada tabel di atas, menunjukkan bahwa responden yang berpendidikan terakhir SMA yaitu sebanyak 12 orang (30\%), Diploma yaitu sebanyak 17 orang (42,5\%), dan responden yang berpendidikan terakhir Sarjana yaitu sebanyak 11 orang $(27,5 \%)$. Dengan demikian mayoritas responden dari karyawan PT. AJB Bumi Putera Gondomanan Yogyakarta berpendidikan terakhir Diploma.

Data Responden Berdasarkan Usia

\begin{tabular}{|c|c|c|}
\hline Usia & Frequency & Percent \% \\
\hline $17-30$ & 7 & $17,5 \%$ \\
\hline $31-40$ & 23 & $57,5 \%$ \\
\hline$>40$ & 10 & $25 \%$ \\
\hline Jumlah & $\mathbf{4 0}$ & $\mathbf{1 0 0} \%$ \\
\hline
\end{tabular}

Berdasarkan tabel di atas, menunjukkan bahwa responden berusia 17-30 tahun yaitu sebanyak 7 orang responden $(17,5 \%)$, responden berusia 31 40 tahun yaitu sebanyak 23 orang responden $(57,5 \%)$, dan responden berusia $>40$ sebanyak 10 orang responden $(25 \%)$. Dengan demikian mayoritas responden dari dari karyawan PT. AJB Bumi Putera Gondomanan Yogyakarta berusia 31-40 tahun.

Data Responden Berdasarkan Status
\begin{tabular}{|l|c|c|}
\hline \multicolumn{1}{|c|}{ Masa Kerja } & Frequency & Percent \% \\
\hline Belum Menikah & 5 & $12,5 \%$ \\
\hline Menikah & 35 & $87,5 \%$ \\
\hline Jumlah & $\mathbf{4 0}$ & $\mathbf{1 0 0} \%$ \\
\hline
\end{tabular}

Berdasarkan tabel di atas, menunjukkan bahwa responden berstatus belum menikah yaitu sebanyak 5 orang responden (12,5\%), dan sebagian responden berstatus menikah yaitu sebanyak 35 orang responden $(87,5 \%)$. Dengan demikian mayoritas responden dari karyawan PT. AJB Bumi Putera Gondomanan Yogyakarta berstatus menikah.

\section{Hasil Penelitian}

1. Hasil Uji Validitas

a. Uji Validitas Faktor Personal (X1)

\begin{tabular}{|c|c|c|c|c|}
\hline $\mathrm{N}$ & \begin{tabular}{|l|} 
Butir \\
\end{tabular} & r hitung & $\mathrm{r}$ tabel & Status \\
\hline 0 & soal & & $\mathrm{n}=28$ & \\
\hline 1 & $\mathrm{X} 1 \_1$ & 0,825 & 0,374 & Valid \\
\hline 2 & $\mathrm{X} 1$ 2 & 0,897 & 0,374 & Valid \\
\hline 3 & $\mathrm{X} 13$ & 0,803 & 0,374 & Valid \\
\hline 4 & $\mathrm{X} 1 \_4$ & 0,887 & 0,374 & Valid \\
\hline 5 & $\mathrm{X} 15$ & 0,821 & 0,374 & Valid \\
\hline 6 & $\mathrm{X} 166$ & 0,844 & 0,374 & Valid \\
\hline 7 & $\mathrm{X1} 7$ & 0,903 & 0,374 & Valid \\
\hline 8 & $\mathrm{X} 188$ & 0,847 & 0,374 & Valid \\
\hline 9 & X1_9 & 0,806 & 0,374 & Valid \\
\hline
\end{tabular}

Dengan melihat tabel di atas maka seluruh item dinyatakan valid karena sesuai dengan kriteria pengujian mengenai validitas atau 
tidaknya suatu butir atau item yang telah dijelaskan.

b. Uji Validitas Faktor Organisasional (X2)

Tahap 1

\begin{tabular}{|c|c|c|c|c|}
\hline \multirow[t]{2}{*}{ No } & \multirow[t]{2}{*}{\begin{tabular}{|l} 
Butir soal \\
\end{tabular}} & \multirow[t]{2}{*}{$\mathrm{r}$ hitung } & $\mathrm{r}$ tabel & \multirow[t]{2}{*}{ Status } \\
\hline & & & $\mathrm{n}=28$ & \\
\hline 1 & $\mathrm{X} 2 \ldots$ & 0,790 & 0,374 & Valid \\
\hline 2 & $\mathrm{X} 22_{2}$ & 0,591 & 0,374 & Valid \\
\hline 3 & $\mathrm{X} 23$ & 0,590 & 0,374 & Valid \\
\hline 4 & $\mathrm{X} 2 \_4$ & 0,309 & 0,374 & Tidak valid \\
\hline 5 & $\mathrm{X} 25$ & 0,686 & 0,374 & Valid \\
\hline 6 & $\mathrm{X} 26$ & 0,730 & 0,374 & Valid \\
\hline 7 & $\mathrm{X} 27$ & 0,734 & 0,374 & Valid \\
\hline 8 & $\mathrm{X} 28$ & 0,763 & 0,374 & Valid \\
\hline 9 & X2_9 & 0,593 & 0,374 & Valid \\
\hline
\end{tabular}

Dari tabel di atas terlihat bahwa 1 item dari instrumen variabel kepemimpinan memiliki $r$ hitung yang lebih kecil dari $\mathrm{r}$ tabel. Sehingga 1 item dinyatakan tidak valid. Item 1,2,3,5,6,7,8,9 dinyatakan valid karena $r$ hitung lebih besar dari nilai $r$ tabel Product Moment, pada taraf signifikan $=5 \%$ $\mathrm{df}=\mathrm{n}-2$ atau $30-2=28$ yang menunjukkan angka sebesar 0,374. Dengan melihat tabel di atas maka peneliti menguji kembali instrumen yang dinyatakan valid, dengan menghilangkan item yang tidak valid. Adapun hasilnya sebagai berikut:

Tahap 2

\begin{tabular}{|c|c|c|c|c|}
\hline \multirow[t]{2}{*}{ No } & \multirow{2}{*}{$\begin{array}{l}\text { Butir } \\
\text { soal }\end{array}$} & \multirow[t]{2}{*}{ r hitung } & $\mathrm{r}$ tabel & \multirow[t]{2}{*}{ Status } \\
\hline & & & $\mathrm{n}=28$ & \\
\hline 1 & $\mathrm{X} 2 \_1$ & 0,800 & 0,374 & Valid \\
\hline 2 & $\mathrm{X} 22$ & 0,561 & 0,374 & Valid \\
\hline 3 & $\mathrm{X} 2{ }_{3}$ & 0,661 & 0,374 & Valid \\
\hline 4 & $\mathrm{X} 25$ & 0,732 & 0,374 & Valid \\
\hline 5 & $\mathrm{X} 266$ & 0,765 & 0,374 & Valid \\
\hline 6 & $\times 27$ & 0,766 & 0,374 & Valid \\
\hline 7 & $\mathrm{X} 28$ & 0,772 & 0,374 & Valid \\
\hline 8 & $\mathrm{X} 29$ & 0,536 & 0,374 & Valid \\
\hline
\end{tabular}

Dengan melihat tabel diatas maka seluruh item dinyatakan valid Karena sesuai dengan kriteria pengujian mengenai validitas atau tidaknya suatu butir atau item yang telah dijelaskan. c. Uji Validitas Faktor NonOrganisasional (X3)

Tahap 1

\begin{tabular}{|c|c|c|c|c|}
\hline \multirow{2}{*}{$\begin{array}{l}\mathrm{N} \\
0\end{array}$} & \multirow[t]{2}{*}{ Butir soal } & \multirow[t]{2}{*}{$\mathrm{r}$ hitung } & $\mathrm{r}$ tabel & \multirow[t]{2}{*}{ Status } \\
\hline & & & $\mathrm{n}=28$ & \\
\hline 1 & $\mathrm{X} 3{ }^{\prime} 1$ & 0,339 & 0,374 & TidakValid \\
\hline 2 & $\mathrm{X3} 2$ & 0,391 & 0,374 & Valid \\
\hline 3 & $\mathrm{X} 33$ & 0,402 & 0,374 & Valid \\
\hline 4 & $\mathrm{X} 34$ & 0,384 & 0,374 & Valid \\
\hline 5 & $\times 35$ & 0,727 & 0,374 & Valid \\
\hline 6 & X3_6 & 0,614 & 0,374 & Valid \\
\hline 7 & $\times 37$ & 0,423 & 0,374 & Valid \\
\hline 8 & $\mathrm{X} 3{ }_{-} 8$ & 0,443 & 0,374 & Valid \\
\hline 9 & X3 9 & 0,265 & 0,374 & Tidak Valid \\
\hline
\end{tabular}

Dari tabel di atas terlihat bahwa 2 item dari instrumen variabel faktor organisasional memiliki $r$ hitung yang lebih kecil dari $\mathrm{r}$ tabel. Sehingga 2 item dinyatakan tidak valid. Item 2,3,5,6,7,8 dinyatakan valid karena $r$ hitung lebih besar dari nilai $r$ tabel Product Moment, pada taraf signifikan $=5 \%$ df $=\mathrm{n}-2$ atau $30-2=28$ yang menunjukkan angka sebesar 0,374.Dengan melihat tabel di atas maka peneliti menguji kembali instrumen yang dinyatakan valid, dengan menghilangkan item yang tidak valid. Adapun hasilnya sebagai berikut:

Tahap 2

\begin{tabular}{|c|c|c|c|c|}
\hline \multirow{2}{*}{\begin{tabular}{|l|}
$\mathrm{N}$ \\
0
\end{tabular}} & \multirow[t]{2}{*}{ Butir soal } & \multirow[t]{2}{*}{$r$ hitung } & $\mathrm{r}$ tabel & \multirow[t]{2}{*}{ Status } \\
\hline & & & $\mathrm{n}=28$ & \\
\hline 2 & $\mathrm{X} 3{ }_{2} 2$ & 0,384 & 0,374 & Valid \\
\hline 3 & $\mathrm{X} 33$ & 0,279 & 0,374 & Tidak Valid \\
\hline 4 & X3_4 & 0,338 & 0,374 & Tidak Valid \\
\hline 5 & $\mathrm{X} 35$ & 0,766 & 0,374 & Valid \\
\hline 6 & X3_6 & 0,656 & 0,374 & Valid \\
\hline 7 & $\mathrm{X} 37$ & 0,499 & 0,374 & Valid \\
\hline 8 & $\mathrm{X} 38$ & 0,537 & 0,374 & Valid \\
\hline
\end{tabular}

Dari tabel di atas terlihat bahwa 2 item dari instrumen variabel faktor organisasional memiliki $r$ hitung yang lebih kecil dari $\mathrm{r}$ tabel. Sehingga 2 item dinyatakan tidak valid. Item 2,5,6,7,8 dinyatakan valid karena $r$ hitung lebih besar dari nilai $r$ tabel Product Moment, pada taraf signifikan $=5 \%$ df $=n-2$ atau $30-2=28$ yang menunjukkan angka sebesar 0,374.Dengan melihat tabel di atas maka peneliti menguji kembali instrumen yang dinyatakan valid, dengan menghilangkan item 
yang tidak valid. Adapun hasilnya sebagai berikut:

Tahap 3

\begin{tabular}{|l|c|c|c|c|}
\hline No & Butir & r hitung & r tabel & Status \\
\cline { 4 - 4 } & soal & & $\mathrm{n}=28$ & \\
\hline 2 & $\mathrm{X} 3 \_2$ & 0,384 & 0,374 & Valid \\
\hline 5 & $\mathrm{X} 3 \_5$ & 0,727 & 0,374 & Valid \\
\hline 6 & $\mathrm{X} 3 \_6$ & 0,761 & 0,374 & Valid \\
\hline 7 & $\mathrm{X} 3 \_7$ & 0,631 & 0,374 & Valid \\
\hline 8 & $\mathrm{X} 3 \_8$ & 0,596 & 0,374 & Valid \\
\hline
\end{tabular}

Dengan melihat tabel di atas maka seluruh item dinyatakan valid karena sesuai dengan kriteria pengujian mengenai validitas atau tidaknya suatu butir atau item yang telah dijelaskan.

d. Uji Validitas Komitmen Karyawan (Y)

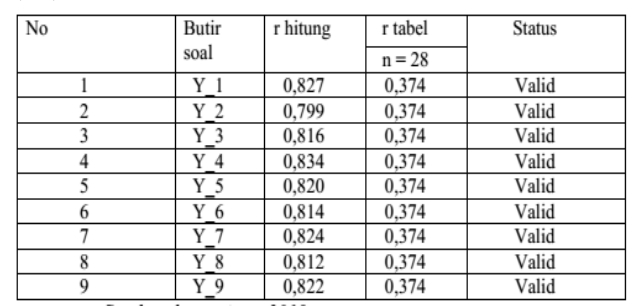

Dengan melihat tabel di atas maka seluruh item dinyatakan valid karena sesuai dengan kriteria pengujian mengenai validitas atau tidaknya suatu butir atau item yang telah dijelaskan.

2. Hasil Uji Reliabilitas

Tabel Hasil Uji Reliabilitas

\begin{tabular}{|c|c|c|c|}
\hline Variabel & $\begin{array}{c}\text { Cronbach' } \\
\text { s Alpha }\end{array}$ & $\begin{array}{c}\text { Rule of } \\
\text { thumb }\end{array}$ & Status \\
\hline Faktor personal $\left(\mathrm{X}_{1}\right)$ & 0,794 & 0,60 & Reliable \\
\hline Faktor organisasional $\left(\mathrm{X}_{2}\right)$ & 0,807 & 0,60 & Reliable \\
\hline $\begin{array}{c}\text { Faktor non organisasional } \\
\left(\mathrm{X}_{3}\right)\end{array}$ & 0,627 & 0,60 & Reliable \\
\hline $\begin{array}{c}\text { Komitmen Organisasional } \\
(\mathrm{Y})\end{array}$ & 0,762 & 0,60 & Reliable \\
\hline
\end{tabular}

Berdasarkan data di atas dapat disimpulkan bahwa nilai cronbach alpha > rule of thumb $(0,6)$ sehingga hasil pengujian reliabilitas untuk variabel faktor personal, faktor organisasional dan faktor non organisasional terhadap komitmen organisasional dinyatakan reliabel.
3. Hasil Uji Regresi Linier Berganda Uji Regresi Linier Berganda

\begin{tabular}{|l|c|}
\hline & $\mathrm{B}$ \\
\hline 1 (constant) & 2,734 \\
Faktor personal & 0,273 \\
Faktor organisasional & $-0,239$ \\
Faktor non organisasion & 0,299 \\
\hline
\end{tabular}

$\mathrm{Y}=2,734+0,273 \mathrm{X} 1-0,239 \mathrm{X} 2+$ 0,299 X3

Setiap nilai persamaan regresi dapat diinterpretasikan sebagai berikut: $\mathrm{a}=2,734$ merupakan nilai konstanta. Jika X1, X2 dan X3 dimisalkan 0, maka nilai dari komitmen organisasional akan meningkat.

$\beta 1=0,273$ berarti apabila variabel faktor personal bersifat positif yang menunjukan bahwa semakin meningkatnya faktor personal maka akan mengakibatkan peningkatan komitmen organisasional, dengan asumsi variabel bebas lainnya dianggap konstan.

$\mathrm{B} 2=-0,239$ berarti apabila variabel faktor organisasional bersifat negatif yang menunjukan bahwa semakin meningkatnya faktor organisasional maka akan mengakibatkan penurunan terhadap komitmen organisasional, dengan asumsi variabel bebas lainnya dianggap konstan.

$\mathrm{B} 3=0,299$ berarti apabila variabel faktor non organisasional bersifat positif yang menunjukan bahwa semakin meningkatnya faktor non organisasional maka akan mengakibatkan peningkatan komitmen organisasional, dengan asumsi variabel bebas lainnya dianggap konstan.

4. Hasil Uji Parsial (Uji T)

a. Pengaruh Faktor Personal Terhadap Komitmen Karyawan.

\begin{tabular}{|c|c|}
\hline Model & Sig \\
\hline Faktor Personal & 0,173 \\
\hline
\end{tabular}


Variabel faktor personal mempunyai nilai $0,173>0,05$. Dengan demikian $\mathrm{H} 1$ diterima atau Ha ditolak, sehingga tidak terdapat pengaruh signifikan antara faktor personal terhadap komitmen organisasional karyawan.

b. Pengaruh Faktor Organisasional Terhadap Komitmen Karyawan.

\begin{tabular}{|c|c|}
\hline Model & Sig \\
\hline Faktor organisasional & 0,296 \\
\hline
\end{tabular}

Variabel faktor organisasional mempunyai nilai $0,296>0,05$. Dengan demikian $\mathrm{H} 2$ diterima atau Ha ditolak, sehingga tidak terdapat pengaruh signifikan antara faktor organisasional terhadap komitmen organisasional karyawan.

c. Pengaruh Faktor Non-Organisasional Terhadap Komitmen Karyawan.

\begin{tabular}{|c|c|}
\hline Model & Sig \\
\hline $\begin{array}{c}\text { Faktor non } \\
\text { organisasional }\end{array}$ & 0,008 \\
\hline Variabel faktor
\end{tabular}

organisasional mempunyai nilai $0,008<0,05$. Dengan demikian H3 ditolak atau Ha diterima, sehingga terdapat pengaruh signifikan antara faktor non organisasional terhadap komitmen organisasinal karyawan.

5. Hasil Uji Simultan (Uji F)

\begin{tabular}{|c|c|}
\hline F Hitung & Sig \\
\hline 3,511 & 0,025 \\
\hline
\end{tabular}

Dari hasil uji regresi linier berganda diperoleh nilai dengan probabilitas sebesar $0,025<0,05$. Dengan demikian $\mathrm{H} 4$ ditolak atau $\mathrm{Ha}$ diterima atau dapat disimpulkan bahwa ada pengaruh signifikan antara faktor peronal, faktor organisasional dan faktor non-organisasional terhadap komitmen organisasional pada PT. AJB Bumi Putera Gondomanan Yogyakarta.
6. Hasil Uji Koefisien Determinasi

\begin{tabular}{|c|c|}
\hline $\mathbf{R}^{2}$ & Nilai \\
\hline R squere & 22,6 \\
\hline
\end{tabular}

Berdasarkan hasil analisis menunjukan nilai R2 adalah 0,226 berarti variabel yang dipilih pada variabel independen (faktor personal, faktor organisasional dan faktor nonorganiasional) dapat menerangkan variasi variabel dependen (komitmen organisasional karyawan) dengan kontribusi $22,6 \%$, sedangkan sisanya $77,4 \%$ diterangkan oleh variabel lain yang tidak dimasukan dalam penelitian ini.

\section{Pembahasan}

1. Pengaruh Faktor Personal Terhadap Komitmen Organisasional Karyawan.

Berdasarkan dari hasil perhitungan diperoleh nilai signifikansi $0,173>$ dari alpha 0,05 sehingga faktor personal (X1) tidak berpengaruh signifikan terhadap komitmen organisasional karyawan (Y). Hasil penelitian ini dapat membuktikan bahwa faktor personal tidak berpengaruh terhadap komitmen karyawan.

Hasil penelitian ini sesuai dengan penelitian yang dilakukan oleh Imada Ulinnuha dengan nilai hasil uji t hitung sebesar 0,276>0,05 yang artinya faktor personal tidak berpengaruh signifikan terhadap komitmen organisasi. Penelitian ini bertentangan dengan teori yang disampaikan oleh Robbins (2014) bahwa faktor personal merupakan hal-hal yang sangat mempengaruhi tingkat komitmen individu. Karyawan yang bekerja lebih lama dan tua, tingkat komitmennya lebih tinggi dibandingkan dengan karyawan yang belum lama bekerja dan usianya masih muda. Jenis kelamin juga mempengaruhi komitmen seseorang terhadap organisasi, karyawan perempuan cenderung lebih komit terhadap organisasi dibandingkan dengan karyawan laki-laki. Pendidikan 
karyawan yang lebih rendah komitmennya lebih tinggi dari karyawan yang berpendidikan tinggi.

Penelitian ini bertentangan dengan hasil penelitian yang dilakukan oleh Sari (2012) dengan nilai hasil uji $\mathrm{t}$ adalah $0,019<0,05$ yang artinya terdapat pengaruh variabel faktor personal terhadap komitmen organisasional.

2. Pengaruh Faktor Organisasional Terhadap Komitmen Organiasional Karyawan.

Berdasarkan dari hasil perhitungan diperolah nilai signifikan $0,296>0,05$ alpha, sehingga faktor personal (X2) tidak berpengaruh terhadap komitmen organisasional karyawan (Y). Hasil penelitian ini dapat membuktikan bahwa faktor organisasional tidak berpengaruh signifikan terhadap komitmen karyawan. Artinya, faktor organisasional tidak dapat menentukan atau berpengaruh terhadap komitmen karyawan.

Hasil penelitian ini sesuai dengan penelitian yang dilakukan oleh Nurul Aisyah dengan Nilai t hitung sebesar $0,279>0,05$ yang artinya faktor organisasional berpengaruh tidak signifikan terhadap komitmen karyawan. Penelitian ini bertentangan dengan teori yang disapmaikan oleh Lincoln dan Bashaw dalam Sopiah (2008) menyebutkan bahwa komitmen karyawan dipengaruhi oleh faktor orgnisasional dan juga bertentangan dengan penelitian sebelumnya yang dilakukan Munandar (2017) dengan nilai sig sebesar $0,030<0,05$ yang artinya dalam penelitian tersebut faktor organisasional berpengaruh terhadap komitmen organisasional karyawan.

3. Pengaruh Faktor Non-Organisasional Terhadap Komitmen Organisasional Karyawan.
Berdasarkan dari hasil perhitungan diperolah nilai signifikan $0,008<0,5$ alpha, sehingga faktor non organisasional (X3) berpengaruh signifikan secara parsial terhadap komitmen organisasional karyawan (Y). Hasil penelitian ini dapat membuktikan bahwa faktor non-organisasional berpengaruh signifikan terhadap komitmen organiasional karyawan.

Dari hasil penelitian ini disimpulkan bahwa faktor nonorganisasional memiliki pengaruh signifikan terhadap komitmen organisasional, artinya semakin tinggi faktor non organisasional maka akan semakin tinggi pula komitmen organisasional. Hal ini sesuai dengan pendapat Steers dan Porter (Sopiah, 2008) yang mengemukakan bahwa salah satu faktor yang mempengaruhi komitmen karyawan pada organisasi, adalah faktor non organisasional, meliputi availability of alternative jobs atau faktor yang bukan berasal dari organisasi, misalnya ada tidaknya alternatif pekerjaan lain.

Tantangan dalam memasuki sebuah organisasi atau tempat kerja baru seperti perbedaan lingkungan dan budaya, perbedaan tersebut mengakibatkan karyawan harus beradaptasi lagi dan akan menghambat karyawan dalam mengekplorasi keahliannya, selain itu juga di dalam organisasi yang baru atasan belum sepenuhnya percaya terhadap kinerja karyawan baru sehingga perlunya karyawan bekerja lebih keras agar mendapat kepercayaan dari atasan. Masa kerja juga merupakan variabel yang paling penting dalam menjelaskan tingkat pengunduran diri karyawan (Robbins, 2014). Semakin lama karyawan bekerja dalam suatu perusahaan semakin kecil kemungkinan karyawan tersebut akan mengundurkan diri.

Penelitian ini juga sesuai dengan penelitian yang dilakukan oleh Husin 
(2014) dengan nilai $\mathrm{t}$ hitung sebesar $0,028<0,05$, artinya faktor nonorganisasional berpengaruh signifikan terhadap komitmen organisasional karyawan.

4. Pengaruh Faktor Personal, Faktor Organisasional dan Faktor NonOrganisasional Terhadap Komitmen Organisasional Karyawan.

Berdasarkan dari hasil perhitungan diperoleh hasil uji $\mathrm{F}$ (uji simultan) variabel independen faktor personal, faktor orgnisasional dan faktor non organisasional secara bersama-sama berpengaruh signifikan terhadap variabel dependen komitmen organisasional. Hal ini dibuktikan dengan signifikansi $0,025<0,05$ jadi pernyataan menunjukan bahwa hipotesis $\mathrm{H} 4$ diterima. Artinya, faktor personal, faktor orgnisasional dan faktor non-organisasional secara bersamasama berpengaruh signifikan terhadap komitmen organisasional.

Penelitian ini sesuai dengan penelitian yang dilakukan oleh Husin (2017) dengan nilai $f$ hitung sebesar $0,000<0,05$ yang artinya faktor personal faktor organisasional dan faktor non-organisasional berpengaruh signifikan secara simultan terhadap komitmen organisasional.

\section{KESIMPULAN DAN SARAN}

\section{Kesimpulan}

1. Dari hasil uji t faktor personal dengan nilai signifikan sebesar 0,173 lebih besar dari 0,05 artinya faktor personal tidak berpengaruh terhadap komitmen organisasional karyawan (Y) PT. AJB Bumi Putera Gondomanan Yogyakarta.

2. Dari hasil uji $t$ faktor organisasional dengan nilai signifikan sebesar 0,296 lebih besar dari 0,05 artinya faktor organisasional tidak berpengaruh terhadap komitmen organisasional karyawan (Y) PT. AJB Bumi Putera Gondomanan Yogyakarta.
3. Dari hasil uji $t$ faktor nonorganisasional dengan nilai signifikan sebesar 0,008 kurang dari 0,05 artinya faktor personal berpengaruh signifikan terhadap komitmen organisasional karyawan (Y) PT. AJB Bumi Putera Gondomanan Yogyakarta.

4. Dari hasil uji F atau uji secara bersamasama faktor personal, faktor organisasional dan faktor nonorganisasional dengan nilai signifikan $0,025<0,05$ yang artinya faktor personal, faktor organisasional dan faktor non-organisasional secara bersama-sama berpengaruh signifikan terhadap komitmen organisasional karyawan PT. AJB Bumi Putera Gondomanan Yogyakarta.

\section{Saran}

1. Bagi Peneliti Selanjutnya

a. Untuk masa yang akan datang dalam mengisi kuisioner sebaiknya responden didampingi langsung oleh peneliti agar informasi yang didapatkan responden lebih cepat dan jelas.

b. Dengan nilai adjusted $\mathrm{R}$ square sebesar $22,6 \%$ dan sisanya $77,4 \%$ dijelaskan variabel lain menunjukan bahwa peneliti selanjutnya membutuhkan penambahan variabel baru seperti teori yang disampaikan oleh Stum (dalam Sopiah, 2008) bahwa ada 5 faktor yang pengaruhi komitmen yaitu budaya keterbukaan, kepuasan kerja, kesempatan personal untuk berkembang, arah organisasi dan penghargaan kerja yang sesuai dengan kebutuhan, yang dimana faktor-faktor tersebut tidak diteliti dalam penelitian ini.

c. Untuk penelitian selanjutnya di harapkan lebih memperhatikan insturmen yang sifatnya negatif agar tidak terjadi kesalahan pengolahan karena insturmen yang negatif sedikit sulit di teliti. 
d. Untuk penelitian selanjutnya di harapkan lebih perhatikan lagi instrumen pada variabel faktor personal agar isntrumen tepat menggambarkan personaliti karyawan

2. Bagi PT. AJB Bumi Putera Gondomanan Yogyakarta.

a. Meningkatkan dan selalu memperhatikan faktor personal karyawannya agar komitmen organisasional karyawan terus meningkat.

b. Terus meningkatkan faktor organisasionalnya atau kepemimipinan di dalam organsiasi agar komitmen organisasional karyawan terus menigkat.

\section{DAFTAR PUSTAKA}

Arishanti, K. I. (2009). Pengaruh Budaya Organisasi Dan Komitmen Organisasional Terhadap Kepuasan Kerja Karyawan. Jurnal Proceeding PESAT. Vol. 3 Oktober. Universitas Gunadarma Depok.

Darmawan. (2017). Pengaruh Gaya Kepemimpinan Terhadap Komitmen Organisasi Melalui Kepuasan Kerja Sebagai Variabel Intervening. Jurnal Studi Accounting Department. Politeknik Negeri Batam.

Ghozali, Imam. (2011). Aplikasi Analisis Multivariate dengan Program IBM SPSS 19. Semarang: Badan Penerbit Universitas Diponegoro.

Greenberg, J. dan Baron, R.A. (2005). Behaviour in Organizations Understanding and Managing The Human Side of Work. Third Edition. Massachuscets: Allin and Bacon.

Husin, Hamid dan Ruhana. (2014). Pengaruh Variabel Personal, Organisasional Dan Non Organisasional Terhadap Komitmen Organisasional. Jurnal Studi Pada Karyawan Perusahaan PT. PLN
(Persero) APJ Malang Distribusi Jawa Timur. Fakultas Ilmu Administrasi Universitas Brawijaya. Malang.

Luthans. (2014). Perilaku Organisasi. (Alih Bahasa V.A Yuwono, dkk), Edisi Bahasa Indonesia. Yogyakarta. Lumbanraja, Prihatin. (2009). Pengaruh Karakteristik Individu, Gaya Kepemimpinan, Beban Kerja, Budaya Organisasi dan Lingkungan Kerja Terhadap Kinerja Pegawai Inspektorat dalam Pengawasan Keuangan Daerah (Studi Empiris pada Pemerintah Kota Medan).

Munandar, Aris. (2017). Pengaruh Faktor Personal, Faktor Organisasional Dan Faktor Non-Organisasional Terhadap Komitmen Organisasional. Jurnal. Universitas PGRI Yogyakarta.

Robert dan Kinicki. (2014). Perilaku Organisasi. Edisi Kesembilan. Jakarta: Salemba Empat.

Robbins, Stephen P. dan Timothy A. Judge. (2014). Perilaku Organisasi. Jakarta: Salemba Empat.

Sari, Fransisca Fitri Kurnia dan Tri Bodroastuti. (2012). Pengaruh Faktor Personal Dan Faktor Non Organisasi Terhadap Komitmen Organisasional (Studi Pada Pegawai Bagian Produksi PT. Kubota Indonesia). Jurnal Kajian Akuntansi dan Bisnis. STIE Wdya Manggala.

Sopiah. (2008). Perilaku Organisasional. Yogyakarta: Andi.

Siswanto. (2013). Manajemen Tenaga Kerja Indonesia, Pendekatan Administratif dan Operasional. Jakarta: Bumi Aksara.

Sugiyono, (2009). Metode Penelitian Kuantitatif, Kualitatif dan $R \& D$. Bandung: Alfabeta.

Thoha. (2010). Kepemimpinan Dalam Manajemen. Jakarta: Rajawali Pers. 
Zurnali, Cut. (2010). Learning

Organization, Competency,

Organizational Commitment And

Customer Orientation: Knowledge

Worker - KerangkaRiset Manajemen

Sumber Daya Manusia Masa

Depan. Bandung: Unpad Press. 